\title{
DINAMICA MISIONARĂ A PAROHIEI ÎN VIZIUNEA PĂRINTELUI IOAN MIHĂLȚAN, EPISCOPUL ORADIEI
}

Alexandru Teompa*

\begin{abstract}
Present research discusses the pastoral - missionary vision of Father Ioan Mihălțan, vision built in four decades of ministering as parish priest in his village of origin, Ohaba, and in 17 years of serving as Archbishop in Eparchy of Oradea. This vision has the advantage of being a practical one, lived and applied, and then secured in writing. The core of missionary ministering for Church is represented by real and authentic experience of communion man God, void of any formalism and ritualism. This communion is to be fully lived through celebration of the parish lithurgical event - Holy Lithurgy and divine worship - afterwards reflected in the life and relationships of people. This is the authentical christian testimony, magnified by the love addressed even to those outside Church, revealing the hospitality and joy of eclesial living the presence of God in the World
\end{abstract}

Keywords: testimony, communion, parish community, liturgical event, spiritual maturity, proselytizing.

\section{Introducere}

Hotărârea Sfântului Sinod al Bisericii Ortodoxe Române de a declara anul 2015 ca an omagial al misiunii parohiei şi mănăstirii astăzi presupune intensificarea şi dinamizarea misiunii Bisericii, provocată săşi armonizeze în permanență glasul şi cuvântul în funcţie de noile cerințe şi transformări ale societății noastre, aflată într-un alert proces de globalizare şi secularizare. Mesajul şi conținutul Evangheliei sunt aceleaşi, însă e nevoie de noi forme şi mijloace pentru transmiterea învățăturii Bisericii. Pentru a avea o misiune pastorală eficientă avem

\footnotetext{
* PhD candidate, Faculty of Theology, University „1 Decembrie 1918”, Alba Iulia, Romania.
} 
nevoie să ne inspirăm din activitatea şi experiența bogată a marilor păstori ai neamului nostru. Un astfel de exemplu este şi Episcopul Ioan Mihălțan al Oradiei, fost preot paroh în perioada comunistă într-un sat transilvănean, confruntat cu un puternic prozelitism neoprotestant. Slujirea sa misionar-pastorală, activitatea ca dascăl de teologie în mai multe centre universitare, precum şi misiunea sa de ierarh al eparhiei Oradiei, constituie un adevărat etalon misionar pentru preoții zilelor noastre.

\section{O viață închinată parohiei}

Episcopul Ioan s-a născut la 27 septembrie 1926 în localitatea Ohaba, județul Alba. A făcut patru clase primare în satul natal, apoi a urmat Liceul greco-catolic Sf. Vasile cel Mare din Blaj, situându-se mereu printre premianţii şcolii. Aici, spre sfârşitul ciclului inferior a liceului, a încolțit în mintea elevului Ioan dorința de a deveni preot în satul său natal. Astfel mărturiseşte el însuşi: „Î́n cursul superior al liceului mă preocupau mai mult planurile de preoție decât şcoala. [...]. Plănuiam chiar rostuiri de viaţă ca preot necăsătorit în satul meu natal, Ohaba""1 .

Era perioada de început al comunismului, când vocația de preot presupunea asumarea unor riscuri, de aceea familia s-a împotrivit ca tânărul Ioan să intre la teologie. „Preot sub comunişti li se părea lor o primejdie pentru mine şi pentru familia noastră, mai ales că voiam să devin preot necăsătorit. Vederile lor de viitor erau sumbre. Te faci preot sub comunişti, ei te vor închide, pe mine mă vor da afară din serviciu, zicea fratele meu, ai noştri vor muri de inimă rea şi astfel vei distruge o familie""2.

Chemarea spre preoție era însă mult mai puternică decât aceste temeri ale familiei, astfel că în 1947 tânărul Ioan s-a înscris la Academia Andreiană din Sibiu, cu acelaşi gând de a reveni ca preot în satul natal. Pregătirea teologică a fost canalizată în totalitate în

\footnotetext{
${ }^{1} \uparrow$ Ioan Mihălțan, Episcopul Oradiei, Experiențe pastorale la parohie, teologie şi episcopie, Oradea, 1995, p. 13.

${ }^{2}$ Ibidem, p. 14.
} 
această direcție, iar în vacanțele şcolare teologul Ioan punea în aplicare la parohia din Ohaba pregătirea preoțească de la Sibiu. În anul IV de teologie a fost hirotonit diacon şi apoi preot, pe seama capelei şcolii, urmând ca la absolvirea facultătiii să fie instalat în parohia Ohaba, unde preotul paroh renunțase în 1951 la parohie, ie ind totodată şi din cler. Deşi mulți dintre profesorii de teologie 1au sfătuit să-şi continue studiile, întrucât fusese un student apreciat şi cu bune rezultate şcolare, dorința de a face misiune în parohie a fost mai puternică. „O parte din părinții profesori căutau să mă convingă că n-are rost să merg preot în sat, dacă ai rămas necăsătorit, ci să mergi la studii mai departe la doctorat, zicând că: «Ce rost are să-ți închini viața unui sat?»" "3. Studiile doctorale l-au aşteptat mai bine de 20 de ani, timp în care şi-a pus în bună rânduială parohia pe care o păstorea. Pe toată durata studiilor, dar şi ca profesor de Indrumări Misionare la Facultatea de Teologie din Sibiu, a rămas paroh la Ohaba şi, după aproape 40 de ani de slujire pastoral-misionară în satul natal, a fost chemat la cea mai înaltă slujire a lui Hristos pe pământ, slujirea arhierească. Ultimul an din viaţă, după retragerea din scaunul arhieresc, 1-a petrecut tot în satul natal, acolo unde este şi înmormântat, la dorința sa. A trecut la cele veşnice la 17 martie 2008.

\section{2. „Întruparea autenticului creştin"}

Ideea fundamentală a misiunii pastorale a Părintelui Episcop Ioan Mihălțan este trăirea unei vieții duhovniceşti reale, ,acea întrupare autentic creştină dusă în viaţa cea de toate zilele, adică printr-o trăire creştină înaltă. Socotesc principală misiunea preotului de a trăi mai întâi el personal, şi apoi credincioşii lui, Evanghelia lui Hristos"4. Peste tot pe unde a activat, Episcopul Ioan a avertizat asupra pericolului de a înlocui trăirea spirituală reală cu activitatea culturală, didactică, socială etc., sau cu un ritualism exterior, deşi

\footnotetext{
${ }^{3}$ Ibidem, p. 22.

${ }^{4}$ Pr. lect. Ioan Mihălțan, Convorbiri duhovniceşti, în Protos. Ioanichie Bălan, Convorbiri duhovniceşti, II, Ed. Episcopiei Romanului şi Huşilor, 1990, p. 179180.
} 
mesajul Părinților Bisericii dintotdeauna este acesta: viața duhovnicească poate compensa anumite activități umane, dar ea nu poate fi înlocuită cu nimic. Este ceea ce exprimă raportul indestructibil, care stă la baza „culturii trinitare a Bisericii: lex orandi, lex credendi, lex agendi, lex convivendi" ", adică aşa cum ne rugăm, aşa credem, aşa acționăm şi aşa ne comportăm cu ceilalți. „Nu vom găsi în Sfânta Scriptură sau în viața Bisericii persoane care să aibă cu adevărat o credință dreaptă şi să nu întrupeze şi o viață îndreptată. În cazurile contrare, de cele mai multe ori, dreapta credință este adumbrită şi falsificată de fumul unor patimi ce stăpânesc ființa umană"’.

Încă din şcoală, părintele Ioan a observat discrepanța dintre teorie şi practică în ceea ce priveşte viaţa creştină. Acest lucru 1-a constatat pe când era elev la Liceul greco-catolic din Blaj, fapt pentru care, deşi s-a încercat convertirea sa la greco-catolicism, nu s-a reuşit. „Cred că atunci, la vârsta de 16-17 ani, eram mult mai curat la suflet decât astăzi şi această curăție lăuntrică depista mai bine legătura dintre formele exterioare şi realitățile spirituale. Observam multe formalisme, începând de la închinăciuni, slujbe, predici, diferențiate de o viață autentic spirituală şi aceste constatări nu mă atrăgeau"7. Acest ritualism gol de esență duhovnicească, ,o părută coajă creștinească, dar fără un miez al autenticului creștin"8, este o contra mărturie pentru preot în slujirea sa. „Fără această realitate trăită şi împropriată în ființa preotului, cuvântul lui mai puţin va zidi în dreapta credință pe alții, sau poate chiar să-i smintească în cele dumnezeieşti, constatare făcută de Sfântul Grigorie de Nazians când

${ }^{5}$ Daniel Munteanu, Pe urmele iubirii. Contribuții trinitare la o cultură a comunicării sfințitoare, Târgovişte, Ed. Bibliotheca, 2013, p. 37.

${ }^{6}$ Pr. lect. Ioan Mihălțan, Metode şi mijloace pastorale pentru intărirea credincioşilor în dreapta credință, în „Mitropolia Banatului”, anul XXXIII, nr. 9-10, septembrie-octombrie, 1983, p. 593.

${ }^{7}$ Idem, Experiențe pastorale...., p. 13.

8 † Ioan Mihălțan, Episcopul Oradiei, Îndrumări pentru îndreptarea şi maturizarea duhovnicească a persoanei noastre, Editura Episcopiei Oradiei, 1994, p. 43. 
zice: «Iulian Apostatul a făcut Bisericii mai puțin rău, decât mulți dintre clericii nedemni de misiunea lor»"

\section{Comuniunea parohială}

În cele patru decenii de slujire la Ohaba, părintele Ioan a avut

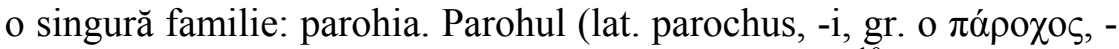
ov) - „cel care furnizează, cel care răspunde, gazda" ${ }^{10}$ - este cel care adună în jurul său, şi prin el, în jurul Sfântului Altar şi al Sfântului Potir întreaga comunitate. „Simbolic, parohia este trupul mistic al lui Hristos, în care viază şi lucrează harul lui Dumnezeu şi în care trebuie să se integreze orice creştin, pentru a fi părtaş la har şi a dobândi mântuirea. Toți creştinii trebuie să aparțină unei parohii, să fie legaţi de acelaşi altar şi aceiaşi slujitori, în care continuă în lume lucrarea mântuitoare a lui Hristos" 11 .

„Administrativ, parohia este celula sau unitatea cea mai mică a Bisericii creştine" 12 , însă prin lucrarea harică de care dispune, ea este deplină, fiind imaginea concretă a Bisericii mari, desăvârşite, a lui Hristos. „Biserica, zice Homiakov, nu este o doctrină; ea nu este un sistem şi nu este nici o instituție. Biserica este un organism viu al adevărului, al slujirii sau, mai exact, adevărul şi iubirea ca organism"13. Comuniunea parohială, puternic afectată astăzi de individualismul şi egocentrismul lumii postmoderne, nu trebuie să-şi caute modele noi pentru a se revigora, întrucât modelul său

${ }^{9}$ Diacon prof. N. Nicolaescu, Răspunderea pastorală şi misionară a preoției după Noul Testament, în „Biserica Ortodoxă Română”, anul XCII, nr. 3-4, 1974, apud Pr. lect. Ioan Mihălțan, Metode şi mijloace ..., p. 594.

${ }^{10}$ Pr. prof. dr. Ene Branişte şi prof. Ecaterina Branişte, Dicționar enciclopedic de cunoştințe religioase, Editura Diecezană Caransebeş, 2001,p. 349.

${ }^{11}$ Ibidem, p. 350.

${ }^{12}$ Cf. Statutului BOR, art. 41, apud Pr. prof. dr. Ene Branişte şi prof. Ecaterina Branişte, Dicționar enciclopedic..., p. 350.

13 G. Lamarine, Unam Loctam, Préface aux cuvre théologique de H.S. Khomiakov, Paris 1939, p. 58, apud Pr. drd. Ioan Mihălțan, Temeiurile teologice ale iubirii creştine, în „Studii Teologice”, anul XXVII, nr. 7-8, septembrie-octombrie, 1975, p. 564. 
fundamental şi etern este comuniunea Persoanelor Sfintei Treimi. „Sa scris mult despre ființa Bisericii. Prin tot scrisul s-a lămurit adevărul că Biserica în esența ei este trăirea comună a oamenilor cu Sfânta Treime, participare în comun a lor la viața lui Dumnezeu""14. Experiența de veacuri a Bisericii mărturisește: „Biserica decurge atât de mult din Treime, încât se poate spune că Treimea însăşi este rădăcina şi modelul Bisericii”"15. „Părintele teologiei ortodoxe româneşti”, Dumitru Stăniloae, spune: „«Biserica absolută a Treimii» este un model normativ, cauza eficientă şi finală a Bisericii oamenilor, comunitatea iubirii reciproce de sus; ea se face modelul şi forța intrinsecă a comunității iubitoare de jos" ${ }^{\prime 16}$.

Părintele Ioan s-a străduit să realizeze o astfel de comuniune parohială, având ca model Taina comuniunii treimice, care nu se închide în auto-suficiență, ci se deschide cu dragoste spre ceilalți. Parohia este acea „,comunitate ospitalieră, care nu trăieşte pentru sine" ${ }^{\prime 17}$, ci este în stare permanentă de deschidere spre ceilalți, de dăruire, de jertfă. Comunităţile neo-protestante sunt elitiste, comuniunea şi dragostea fiind preferenţiale, iar membrii lor sunt doar „cei aleşi, cei buni, cei desăvârşiți”, excluzându-i pe cei păcătoşi. Preotul este dator să îi primească pe toți, fără părtinire. „Am spus şi repet mereu că reuşita şi succesul unui preot în parohie constă în aceea de a-i cinsti pe toți credincioşii şi să nu disprețuieşti pe nici unul, orice slăbiciuni ar avea" ${ }^{18}$. Atitudinea părintelui duhovnicesc față de cei păcătoşi trebuie să coincidă cu atitudinea lui Hristos, care

14 Teologia Dogmatică şi Simbolică, Manual pentru Institutele Teologice, Bucureşti, 1958, p. 770, apud Pr. Ioan Mihălțan, Comuniunea în cultul Bisericii Ortodoxe, în „Ortodoxia”, anul XXXVII, nr. 1, ianuarie-martie, 1985, p. 196.

${ }^{15}$ Pr. drd. Ioan Mihălțan, Temeiurile teologice..., p. 564.

${ }^{16}$ Pr. prof. dr. Dumitru Stăniloae, Mişcarea ecumenică şi unitatea creştină în stadiul actual, în „Ortodoxia”, XV, nr. 3-4, 1963, p. 552, apud Pr. drd. Ioan Mihălțan, Temeiurile teologice..., p. 564.

${ }^{17}$ Pr. prof. dr. Ion Bria, Orientarea misionară a parohiei, în „Glasul Bisericii”, anul XLVI, nr. 1, ianuarie-februarie, 1987, p. 58.

18 † Ioan Mihălțan, Episcopul Oradiei, Experiențe pastorale..., p. 102; Idem, Îndrumări pentru îndreptarea ..., p. 88. 
,în tot timpul propovăduirii Sale, nu a avut nici o atitudine de dispreț faţă de nici un om întâlnit în cale, deşi S-a întâlnit cu o mare păcătoasă, cu un vameş, cu unul care L-a trădat şi, în cele din urmă, cu cei care L-au răstignit" "19. Superioritatea şi disprețul faţă de semeni, oricât de decăzuți ar fi, nu îşi au locul în inima omului credincios. „Şi dacă nu reuşim «să stăm bine» în frumuseți de înaltă sfințenie, cel puțin să stăm «cu duh umilit, inimă înfrântă şi smerită, pe care Dumnezeu nu o va părăsi» (Ps 50,18$)^{, 20}$.

\section{Atitudinea față de prozelitismul neoprotestant}

Problema atitudinii față de prozelitismul neoprotestant este tratată cu mult tact pastoral în scrierile episcopului Ioan. Experiența duhovnicească de patru decenii a ierarhului s-a cristalizat într-un mediu în care prozelitismul baptist era deosebit de activ. Ne-am aştepta ca tonul părintelui în această privință să fie unul ofensiv, cu accente virulente, dar constatăm cu surprindere o atitudine părintească, ce reflectă profunda maturitate duhovnicească a ierarhului.

„Una dintre cele mai grele predici de ținut este aceea contra invățăturilor greşite ale altor culte. De ce? Pentru că ea trebuie să intrupeze simțăminte părinteşti, din care reiese că te dor aceste abateri ale unor persoane şi ascultătorii să citească aceste simțăminte în inima preotului. Dacă aruncăm asupra lor cuvinte de ocară, poporul va răspunde: ce are popa cu ei, că şi aceştia sunt oameni? Dacă nu reuşim să ne ridicăm la astfel de realități spirituale, atunci e mai bine să tăcem şi să învățăm prin tăcere, de care învățătură avem o aşa mare lipsă ${ }^{, 21}$.

Preotul trebuie să fie părinte pentru toți, chiar şi pentru cei de alte confesiuni, învăţându-i şi îndrumându-i pe toți, nu doar prin

\footnotetext{
${ }^{19}$ Idem, Metode şi mijloace..., p. 601.

${ }^{20}$ Ibidem.

21 † Ioan Mihălțan, Episcopul Oradiei, Pastorală la Praznicul Naşterii Domnului - 2003, în „Legea Românească”, anul XIV, nr. 4, 2003, p. 4.
} 
cuvânt, ci mai ales prin propria sa viață morală, prin propria sa grijă şi atenție faţă de toți. Este mărturia creştină cea mai autentică, mărturia prin sfințenia vieții. În viaţa Bisericii noastre avem nenumărate exemple în acest sens, dar poate cel mai elocvent este exemplul Sfântului Vasile cel Mare, care, în vestitele sale Vasiliade - aşezăminte de caritate susținute de Biserică -, ,,a adunat suferinzi de diferite etnii şi religii, iar la moartea sa, cu toții, evrei, păgâni şi creștini deopotrivă, se tânguiau zicând: A murit părintele nostru"22. Drumul pe care trebuie să-l urmeze preotul şi păstoriții săi, pentru a ajunge la mărturia creştină autentică, e schițat în mod plastic în Pastoralele episcopului Ioan: „Dacă nu coborâm din întunericul mândriei în adâncul smereniei, ca să urcăm spre piscul iubirii, dacă nu lăsăm plăcerea şi nu urcăm prin înfrânare spre înțeleapta cumpătare, s-ar putea întâmpla să rămânem în tufişurile înguste ale lucrurilor şi să auzim, ca un ecou de departe, din istorie, pe marele Eminescu: «trăind în cercul vostru strâmt...»"

Dragostea potențează toate eforturile pastorale ale preotului, dând sens şi conținut mărturiei sale. „Această putere frumoasă a iubirii va înfrumuseța şi cuvântul propovăduit, şi va crea astfel o atmosferă duhovnicească, care duce la o citire lăuntrică, dincolo de cuvântul rostit” ${ }^{24}$ al Sfintei Scripturi. Prin energia negativă a orgoliului şi a autosuficienței, versetele Scripturii devin „pietre” sau „arme de luptă”, cu care sectarii vor să-i înfrângă pe oamenii Bisericii. Răspunsul ortodox, pe deplin verificat de experiența preotului, şi apoi a Episcopului Ioan, este iubirea. Aceasta este proba de foc a oricărui creştin. Episcopul Ioan mărturiseşte: „Problema este greu de rezolvat şi datorită faptului că de obicei neoprotestanții au o atitudine fără respect mai ales faţă de preot, ştiind că este singura persoană asupra căreia nu au nădejde de a o converti la credința lor. Şi nu rareori răspundem şi noi cu aceeaşi monedă",25.

\footnotetext{
${ }^{22}$ Idem, Cuvântări la Marile Praznice, Oradea, Editura Episcopiei Ortodoxe Române a Oradiei, Bihorului şi Sălajului, 2001, p. 113.

${ }^{23}$ Ibidem, p. 31.

${ }^{24}$ Idem, Pastorală la Praznicul Naşterii Domnului - 2003..., p. 4.

${ }^{25}$ Idem, Experiențe pastorale..., p. 55.
} 
„Fenomenul sectar este tocmai urmarea sărăciei întru iubire. Sectanţii se despart de trupul Bisericii tocmai prin lipsa de iubire. «Iubirea» lor este amestecată cu interes şi cu fanatism. Sectarii produc certuri şi dezbinări nu numai în Biserică, în parohie, ci chiar şi în familii. Or, dacă cineva în numele lui Hristos, cu Biblia în mână, desparte pe credincioşi de Biserică, dezbină oamenii, acela nu lucrează în numele lui Hristos. «Căci dragostea lui Hristos uneşte» (cf. 2 Co 5, 14), nu dezbină, nu scoate din Biserică"26.

Episcopul Ioan a văzut în apariţia şi dezvoltarea sectelor neoprotestante în România o lovitură grea adusă unităţii naţionale şi spirituale a poporului român, „o fisură păgubitoare în caracterul sănătos al creştinului de totdeauna"27. De fapt, toată teologia misionară a secolului al XX-lea, reprezentată de Vasile Ispir, Petru Deheleanu, Grigore Comşa, P. I. David, Ion Bria, Ilie Cleopa, Ioan Mihălțan, etc., a avertizat asupra acestui pericol.

„De reținut este că, în combaterea acestor noi secte, se făcea apel nu doar la argumente de ordin biblic şi teologic, ci şi la argumente de ordin național, noile mişcări religioase fiind privite nu doar ca o amenințare la adresa adevăratei Biserici a lui Hristos, cea ortodoxă, ci şi ca o amenințare la adresa unității naționale româneşti (motivația fiind proveniența alogenă, precum şi sprijinul extern de care beneficiau reprezentanții sectelor) ${ }^{, 28}$.

\footnotetext{
${ }^{26}$ Pr. prof. dr. Valer Bel, Misiune, parohie, pastorație. Coordonate pentru o strategie misionară, Ediția a II-a, Cluj Napoca, Editura Renaşterea, 2006, p. 127.

${ }^{27} \dagger$ Ioan Mihălțan, Episcopul Oradiei, Experiențe pastorale..., p. 4.

${ }^{28}$ Pr. prof. dr. Aurel Pavel, Reflecții critice asupra misiunii creştine, Sibiu, Editura Andreiană, 2014, p. 271.
} 
De altfel, Episcopul Ioan face apel în permanență la ,acea

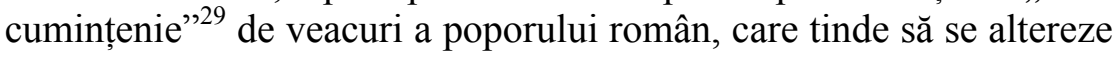
prin dezbinarea şi dezordinea aduse de sectari. Părintele Rafail Noica spune că „Ortodoxia este firea omului”, ${ }^{30}$, iar părintele Dumitru Stăniloae vorbeşte despre alterarea ontologică, ființială, a românului, prin pierderea Ortodoxiei.

„Să ne oprim un moment doar asupra îngâmfärii sectare. Cine nu cunoaşte inălțimea de la care priveşte sectarul pe oricine nu e din gruparea lui? Şi cine n-a auzit pe indiferent care sectar afirmând că el ințelege deplin toate tainele dumnezeieşti şi e desăvârşit sub raportul moral, deasupra oricărui păcat? Ce străină ne apare această psihologie comparată cu sincera, netrâmbițata, cu naturala smerenie ortodoxă şi românească! Se va mai mândrind el românul pe alte terenuri ale vieții, pentru alte motive, dar pe teren religios, pentru motive de bunătate şi evlavie nu s-a văzut în religiozitatea noastră tradițională nici o urmă de mândrie. Gospodarii cei mai evlavioşi, mai bisericoşi, îşi afişau şi trâmbițau mai puțin evlavia. Poporul nostru ştie că sfinții cei mai venerați ai Bisericii ne dau o pildă elocventă în această privință $[. .$.$] . Chiar dacă se intâlneşte mândria şi la român, ea$ este o manifestare involuntară, nu voluntară ${ }^{, 31}$.

Prin activitatea misionar-pastorală depusă cu atâta devotament şi jertfelnicie, părintele Ioan a realizat, prin exemplul său personal, ceea ce enunța în aceeaşi perioadă marele nostru misiolog, părintele profesor Ion Bria: „Preotul trebuie să ajute

${ }^{29}$ Episcopul Ioan îşi încheie aproape toate pastoralele sale cu îndemnul de a redescoperi: ,acea cumințenie românească a înaintaşilor şi strămoşilor noştri”" (în Cuvântări la Marile Praznice..., p. 9), ,acele frumuseți duhovniceşti ale moşilor şi strămoşilor noştri” (în Cuvântări la Marile Praznice..., p. 86), „,acea naturalețe plină de sinceritate, frică de Dumnezeu şi smerenie neprefăcută" (în Cuvântări la Marile Praznice..., p. 105) a neamului românesc din totdeauna. ${ }^{30}$ Ieromonahul Rafail Noica, Cultura Duhului, Alba Iulia, Editura Reîntregirea, 2002 , p. 113.

${ }^{31}$ Pr. prof. dr. Dumitru Stăniloae, Ortodoxie şi românism, Opere complete VIII, Bucureşti, Editura Basilica a Patriarhiei Române, 2014, p. 78. 
parohia să-şi cristalizeze răspunsul ei eclezial [...] să dea un răspuns viu comunitar" ${ }^{\prime 2}$ tuturor provocărilor cu care se confruntă.

\section{Redescoperirea izvorului haric al Sfintelor Taine şi a frumuseții cultului ortodox}

Forța misionară a preotului izvorăşte din trăirea vie şi reală a cultului Bisericii Ortodoxe. Aceasta este esența slujirii preoțeşti, sugerate atât de bine de icoana coborârii lui Hristos la iad, socotită pe deplin o icoană a Învierii. „În această scenă, în vreme ce Hristos prinde pe Eva de încheietura mâinii, lui Adam şi drepților le arată potirul Sfintei Euharistii, pentru a le împărtăşi şi lor din rodul jertfirii Sale, «leacul nemuririi»" "33. Aici, în „Potirul nemuriri” îşi au începutul toate, păstrarea şi transmiterea dreptei credințe şi viața religios-morală, cât şi slujirea semenilor şi închegarea deplină a comuniunii parohiale. Patriarhul Iustin Moisescu sublinia importanța cultului divin:

„....mai mult decât orice alt moment, în timpul slujbei religioase comune, în biserică se manifestă unirea comună a credincioşilor. În această ambianță specifică de inălțare şi de intimitate religioasă, scara care urcă spre cer devine o realitate; credincioşii sunt casnicii sfinților, locuitori ai casei lui Dumnezeu (Efes. 2,19). In acel moment dispare tot ceea ce este individual, ca omul ieşind din propriile sale margini, să devină intr-un fel, unul cu semenii săi, în comuniune cu $e i^{, 34}$.

${ }^{32}$ Pr. prof. dr. Ion Bria, Aspecte ale pastorației misionare in situația prezentă, „Glasul Bisericii”, anul XLVI, nr. 1, ianuarie-februarie, 1987, p. 61.

${ }_{33} \dagger$ Ioan Mihălțan, Episcopul Oradiei, Recenzie la „Wilhelm Nyssen, Flacăra mântuirii. Frescele Bisericii Ortodoxe Sf. Ioan Botezătorul Ferentari din Bucureşti, traducere de Ioan Alexandru, Bucureşti, 1986”, în „Mitropolia Ardealului", anul XXXV, nr. 1, ianuarie-februarie, 1990, p. 114.

${ }^{34}$ Patriarhul Iustin, Cuvântare tinută în catedrala reformată din Paris, în „Mitropolia Moldovei şi Sucevei”, nr. 1-2, 1963, p. 34, apud Pr. lector Ioan Mihălțan, Preocupări pastoral-misionare în opera pre Fericitului Patriarh 
Părintele Ioan, pe atunci lector la Facultatea de Teologie Ortodoxă din Sibiu, referindu-se la slujirea misionară a preotului, spunea:

,Socotesc ca metodă principală viața impecabilă a preotului şi săvârşirea slujbelor din sfânta biserică intr-o atmosferă de evlavie sinceră in fața lui Dumnezeu. Avem, precum am mai spus, slujbe pe care nu le au alte culte, pentru orice ocazii, pline de miez dogmatic şi duhovnicesc. Se pare că această comoară duhovnicească nu a fost indeajuns prețuită şi cunoscută. S-o facem cunoscută şi simțită in inimile credincioşilor noștri!" 35

Menirea preoției constă, în primul rând, în păstrarea legăturii neîntrerupte cu Dumnezeu prin rugăciune, şi de a-i inspira, totodată, şi pe enoriaşii săi în această direcție. „Datoria preotului este nu numai de a se ruga el, ci şi de a-i învăța pe alții să se roage, dându-le deprinderea rugăciunii. Starea de har şi de religiozitate o decide preotul. El trebuie să fie şi să se arate ca un om al rugăciunii prin excelență, atât prin a mijloci transmiterea harului dumnezeiesc, cât şi pentru a infiltra gustul, necesitatea şi felul de a se ruga păstoriţilor săi” ${ }^{36}$. Acesta trebuie să fie legământul tainic, spiritual al oricărui preot. „Preotul are printre alte meniri şi pe aceea de a întreține şi inteți focul rugăciunii în casa lui David, în parohia şi în biserica lui. Vai de preotul care nu se roagăa, care nu a luptat să-şi câş̧tige deprinderea rugăciunii, care nu vede în slujba dumnezeiască decât o povară, care a stins în sine duhul rugăciunii”" ${ }^{37}$.

Iustin, în „Mitropolia Ardealului”, anul XXXI, nr. 2, martie-aprilie, 1986, p. 155.

${ }^{35}$ Pr. lector Ioan Mihălțan, Convorbiri duhovniceşti..., p. 186.

${ }^{36}$ Pr Petre Vintilescu, Preotul în fața chemării sale de păstor al sufletelor, Bucureşti, 1934, p. 273, apud Pr. prof. Ene Branişte, Vocație şi responsabilitate în slujirea preoțească, Bucureşti, Editura Basilica, 2014, p. 84.

${ }^{37}$ Pr. Dumitru Stăniloae, Sublimitatea preoției, în „Mitropolia Olteniei”, anul IX, nr. 5-6, 1957, p. 308, apud pr. prof. Ene Branişte, Vocație şi responsabilitate...pp. 83-84. 
În cei 40 de ani de pastorație la parohie, dar şi ca ierarh, părintele Ioan a avut o grijă deosebită față de sfintele slujbe: a format cântăreți buni, cărora le-a sădit în suflet conştiința rugăciunii şi trăirii în prezența lui Dumnezeu prin cântarea liturgică; a instituit în biserică liniştea, care împreună cu cântarea atentă şi cu paza gândurilor, creează atmosfera tainică de sfințenie; a inspirat credincioşilor, prin exemplul său, punctualitatea şi prezența regulată la serviciul liturgic divin. „Cu multă nostalgie îmi aduc aminte de tainicele şi ziditoarele momente liturgice trăite aici, fapt pentru care am rămas mult legat de oamenii şi biserica din satul meu"38, mărturiseşte părintele Ioan.

După înscrierea la cursurile de doctorat, la îndemnul îndrumătorului său - părintele Dumitru Stăniloae -, părintele Ioan a aprofundat sistematic şi ştiințific importanța şi conținutul cărților de slujbă ale Bisericii Ortodoxe, rămânând „uimit de bogăția de teologie ortodoxă cuprinsă în aceste cărți înțelepte" şi recomandând tuturor ca ,în fruntea cărților din biblioteca noastră, cărțile de slujbă să ocupe un loc de cinste, imediat după Sfânta Scriptură’39. În cadrul sfintelor slujbe, cuvântul devine hrană şi viaţă, nu doar simplă informație sau mijloc de combatere a celorlalți, ca în cazul prozelitismului sectar. „Părinții nu citeau textele, ci pe Hristos cel pururea viu. Hristos le vorbea şi ei consumau cuvântul Lui ca pâinea şi vinul euharistic”40. Tradiția patristică evidențiază importanța unirii dintre Cuvânt şi Taină, adică Biserica nu doar tâlcuieşte corect şi autentic cuvântul lui Dumnezeu, dar şi împărtăşeşte credincioşilor săi harul mântuitor al Sfintelor Taine. „Biserica nu este o şcoală de învățământ teologic, cu scopul în el însuşi, ci lacul Vitezda, pentru

\footnotetext{
38 † Ioan Mihălțan, Episcopul Oradiei, Experien e pastorale..., p. 38.

${ }^{39}$ Idem, Idei din Sfintele Evanghelii pentru predicile duminicilor şi sărbătorilor de peste an, Editura Episcopiei Ortodoxe Române a Oradiei, 1999, p. 4.

${ }^{40}$ Paul Evdokimov, Le sacerdoce royal, Paris, 1968, p. 12, apud Pr. lector Ioan Mihălțan, Preocupări pastoral-misionare..., pp. 160-161.
} 
toți cei care cred, lacul sfinţitor şi mântuitor, în care e activă în continuu puterea lui Dumnezeu"41.

\section{Concluzii}

Viziunea misionar-pastorală a Episcopului Ioan, enunțată în lucrările sale, reprezintă un reper spiritual important pentru lucrarea misionară a Bisericii. Această viziune are avantajul de a fi fost mai întâi trăită şi aplicată în parohie, şi apoi fixată în scris, de aceea vădeşte o puternică experiență misionară, bazată pe înțelepciune şi echilibru pastoral, pe maturitate duhovnicească şi o conştiinţă preoțească responsabilă şi vie. Mărturia creştină eficientă şi autentică, într-o lume dezorientată, este mărturia prin sfințenia vieții, prin curăția inimii şi integritatea sufletului, mărturie pe care nimeni nu o poate contesta. Această mărturie este potențată de iubirea eclesială, ce se manifestă prin trăirea evenimentului liturgic, al intimității comuniunii parohiale cu Dumnezeu, şi care se revarsă apoi spre ceilalți, până dincolo de zidurile bisericii, ca o prelungire a ospitalității şi bucuriei poporului lui Dumnezeu.

\section{Bibliografie}

1. Bel, Valer, Misiune, parohie, pastorație. Coordonate pentru o strategie misionară, Ediția a II-a, Cluj Napoca, Editura Renaşterea, 2006.

2. Branişte, Ene, şi Branişte, Ecaterina, Dicționar enciclopedic de cunoştințe religioase, Editura Diecezană Caransebeş, 2001.

3. Branişte, Ene, Vocație şi responsabilitate in slujirea preoțească, Bucureşti, Editura Basilica, 2014.

4. Bria, Ion, Aspecte ale pastorației misionare în situația prezentă, în „Glasul Bisericii”, anul XLVI, nr. 1, ianuarie-februarie, 1987.

5. Idem, Orientarea misionară a parohiei, în „Glasul Bisericii”, anul XLVI, nr. 1, ianuarie-februarie, 1987.

${ }^{41}$ Pr prof. Dumitru Stăniloae, Sfântul Duh în Revelație şi în Bisericăa în „Ortodoxia”, nr. 2, 1974, p. 238, apud Pr. lector Ioan Mihălțan, Bisericăă, Tradiție, Scriptură, în „Ortodoxia”, anul XXXVIII, nr. 4, octombrie-decembrie, 1988, p. 68. 
6. Mihălțan, Ioan, Biserică, Tradiție, Scriptură, în „Ortodoxia”, anul XXXVIII, nr. 4, octombrie-decembrie, 1988.

7. Idem, Comuniunea în cultul Bisericii Ortodoxe, în „Ortodoxia”, anul XXXVII, nr. 1, ianuarie-martie, 1985.

8. Idem, Convorbiri duhovniceşti, în „Protos. Ioanichie Bălan, Convorbiri duhovniceşti”, II, Ed. Episcopiei Romanului şi Huşilor, 1990.

9. Idem, Cuvântări la Marile Praznice, Oradea, Editura Episcopiei Ortodoxe Române a Oradiei, Bihorului şi Sălajului, 2001.

10. Idem, Experiențe pastorale la parohie, teologie şi episcopie, Oradea, 1995.

11. Idem, Idei din Sfintele Evanghelii pentru predicile duminicilor şi sărbătorilor de peste an, Editura Episcopiei Ortodoxe Române a Oradiei, 1999.

12. Idem, Îndrumări pentru îndreptarea şi maturizarea duhovnicească a persoanei noastre, Editura Episcopiei Oradiei, 1994.

13. Idem, Metode şi mijloace pastorale pentru întărirea credincioşilor în dreapta credință, în „Mitropolia Banatului”, anul XXXIII, nr. 9-10, septembrie-octombrie, 1983.

14. Idem, Pastorală la Praznicul Naşterii Domnului - 2003, în „Legea Românească", anul XIV, nr. 4, 2003.

15. Idem, Preocupări pastoral-misionare în opera Prea Fericitului Patriarh Iustin, în „Mitropolia Ardealului”, anul XXXI, nr. 2, martie-aprilie, 1986.

16. Idem, Recenzie la „Wilhelm Nyssen, Flacăra mântuirii. Frescele Bisericii Ortodoxe Sf. Ioan Botezătorul Ferentari din Bucureşti, traducere de Ioan Alexandru, Bucureşti, 1986”, în „Mitropolia Ardealului", anul XXXV, nr. 1, ianuarie-februarie, 1990.

17. Idem, Temeiurile teologice ale iubirii creştine, în „Studii Teologice”, anul XXVII, nr. 7-8, septembrie-octombrie, 1975.

18. Munteanu, Daniel, Pe urmele iubirii. Contribuții trinitare la o cultură a comunicării sfințitoare, Târgovişte, Ed. Bibliotheca, 2013.

19. Noica, Rafail, Cultura Duhului, Alba Iulia, Editura Reîntregirea, 2002.

20. Pavel, Aurel, Reflecții critice asupra misiunii creştine, Sibiu, Editura Andreiană, 2014.

21. Stăniloae, Dumitru, Ortodoxie şi românism, Opere complete VIII, Bucureşti, Editura Basilica a Patriarhiei Române, 2014. 